\title{
ENZYMATIC TECHNOLOGY TO IMPROVE OIL EXTRACTION FROM Caryocar brasiliense CAMB (PEQUI) PULP. ${ }^{1}$
}

\author{
RENATA GOMES DE BRITO MARIANO², SONIA COURI ${ }^{3}$, SUELY PEREIRA FREITAS ${ }^{4}$
}

ABSTRACT-The present study aims to compare yield and quality of pequi pulp oil when applying two distinct processes: in the first, pulp drying in a tray dryer at $60^{\circ} \mathrm{C}$ was combined with enzymatic treatment and pressing to oil extraction; in the second, a simple process was carried out by combining sun-drying pulp and pressing. In this study, raw pequi fruits were collected in Mato Grosso State, Brazil. The fruits were autoclaved at $121^{\circ} \mathrm{C}$ and stored under refrigeration. An enzymatic extract with pectinase and CMCase activities was used for hydrolysis of pequi pulp, prior to oil extraction. The oil extractions were carried out by hydraulic pressing, with or without enzymatic incubation. The oil content in the pequi pulp $(45 \% \mathrm{w} / \mathrm{w})$ and the physicochemical characteristic of the oil was determined according to standard analytical methods. Free fatty acids, peroxide values, iodine and saponification indices were respectively $1.46 \mathrm{mgKOH} / \mathrm{g}$, $2.98 \mathrm{meq} / \mathrm{kg}, 49.13$ and 189.40 . The acidity and peroxide values were lower than the obtained values in commercial oil samples, respectively $2.48 \mathrm{mgKOH} / \mathrm{g}$ and $5.22 \mathrm{meq} / \mathrm{kg}$. Aqueous extraction has presented lower efficiency and higher oxidation of unsaturated fatty acids. On the other hand, pequi pulp pressing at room temperature has produced better quality oil. However its efficiency is still smaller than the combined enzymatic treatment and pressing process. This combined process promotes cellular wall hydrolysis and pulp viscosity reduction, contributing to at least $20 \%$ of oil yield increase by pressing.

Index Terms: Caryocar brasiliense, sun drying, hydraulic pressing, oil quality index.

\section{TECNOLOGIA ENZIMÁTICA PARA MELHORAR A EXTRAÇÃO DO ÓLEO DA POLPA DE Caryocar brasiliense (PEQUI)}

\begin{abstract}
RESUMO - O presente estudo tem como objetivo comparar o rendimento e a qualidade do óleo da polpa de pequi obtido por dois processos distintos: no primeiro, a secagem da polpa, conduzida em secador de bandeja a $60^{\circ} \mathrm{C}$, foi combinada com tratamento enzimático e prensagem para extração de óleo, no segundo, um processo mai simples foi realizado combinando-se a secagem da polpa ao sol seguida da prensagem a frio. Neste estudo, frutos de pequi in natura foram coletados no estado do Mato Grosso, Brasil. Os frutos foram auto-clavados a $121^{\circ} \mathrm{C}$ e armazenados sob refrigeração. Um extrato enzimático com atividades pectinase e CMCase foi utilizado para a hidrólise da polpa de pequi antes da extração do óleo. O processo de extração foi realizado por prensagem hidráulica, com ou sem incubação enzimática. O teor de óleo na polpa do pequi $(45 \% \mathrm{w} / \mathrm{w})$ e as características físico-químicas do óleo foram determinados de acordo com métodos analíticos oficiais. O teor de ácidos graxos livres, os índices de peróxido, de iodo e de saponificação foram respectivamente de 1,46 $\mathrm{mgKOH} / \mathrm{g}, 2,98 \mathrm{meq} / \mathrm{kg}, 49,13$ e 189,40. A acidez e os valores de peróxido foram inferiores aos valores obtidos em amostras comerciais de óleo vegetal, respectivamente, $2,48 \mathrm{mgKOH} / \mathrm{g}$, $5,22 \mathrm{meq} / \mathrm{kg}$. A extração aquosa apresentou menor eficiência e promoveu uma maior oxidação dos ácidos graxos insaturados. Por outro lado, a polpa de pequi prensada, após secagem ao sol, produziu um óleo de melhor qualidade. No entanto, sua eficiência ainda é menor do que no processo combinado onde se aplicou o tratamento aquoso enzimático seguido da prensagem. O processo combinado promove a hidrólise da parede celular e a redução da viscosidade da polpa, contribuindo com pelo menos $20 \%$ de aumento na produtividade da etapa de extração do óleo por prensagem.
\end{abstract}

Termos para indexação: Caryocar brasiliense, secagem ao sol, prensagem hidráulica, índices de qualidade do óleo.

\footnotetext{
${ }^{1}$ (Trabalho 208-08). Recebido em: 04-08-2008. Aceito para publicação em: 17-04-2009.

${ }^{2}$ M.Sc. Universidade Federal Rural do Rio de Janeiro, BR-465, Km 7, Seropédica, Rio de Janeiro - RJ. CEP: 23.890-000. E-mail: renatagbm@yahoo.com.br.

${ }^{3}$ D.Sc. Embrapa Agroindústria de Alimentos. Av. das Américas, 29501-Guaratiba, CEP: 23020-470, Rio de Janeiro- Brasil. Tel. 55 21 24109618, fax: 5521 24109529; e-mail: scoury@ctaa.embrapa.br.

${ }^{4}$ D.Sc. UFRJ/Escola de Química/DEQ; Ilha do Fundão, Centro de Tecnologia, Bloco E, sala 207. CEP: 21949-900, Rio de Janeiro Brasil. Tel. 5521 25627634, e-mail: freitasp@eq.ufrj.br.
} 


\section{INTRODUCTION}

The cerrado occupies about $21 \%$ of Brazilian territory with a great fauna and flora diversity. The knowledge on Brazilian cerrado is still very scarce, but it is possible to estimate its species richness as being $30 \%$ of the total in Brazil. The C. brasiliense is widely distributed in Brazilian cerrado mainly in Minas Gerais, Mato Grosso and Goiás States. Pequi fruits (Caryocar brasiliense) are an important option of income and food for the populations living in the cerrado regions of Brazil. Its fruits are mainly consumed "in natura" as well as prepared as juices, ice creams, liquors, jellies and specially the traditional dishes which are famous throughout Brazil (Roesler et al; 2008).

In three different areas evaluated in the north of Minas Gerais State, those species presented about 15 to 40 plants/ha. The production of flowers of C. brasiliense start in July and August and fruits in September and October with production peaks in November, during the beginning of the rainy season in that area. In the cerrado region, 30\% of Caryocar brasiliense trees present height between 1.5 and $3.0 \mathrm{~m}$, and $60 \%$ is higher than 3.0 meters. The dimensions of pequi fruits were similar in all areas: width $6.19 \pm 0.20 \mathrm{~cm}$, length $7.71 \pm 0.24 \mathrm{~cm}$, height $6.43 \pm 0.15 \mathrm{~cm}$, volume of $314.90 \pm 20.93 \mathrm{~cm}^{3}$ and a average gross weight of $158.49 \pm 8.14$ $\mathrm{g}$, with a minimum and maximum of 84 and 270 g, respectively (Leite et al., 2006).

The most valuable components of pequi pulp and seeds are their oils, being rich in unsaturated fatty acids, vitamins, carotenoids and phenolic acids (Lima, et al., 2007). The main fatty acids in the pequi pulp oil are oleic and palmitic acids, $60 \%$ and $34 \%$, respectively. Different of the other palm fruits, the fatty acid composition of nut oil is similar to the pulp oil, $56 \%$ and $32 \%$ of oleic and palmitic acids, respectively. The pequi pulp oil is traditionally used as tonic agent in popular medicine due to its natural antioxidants. Its main carotenoids are violaxanthin, lutein and zeaxanthin, with smaller amounts of $\beta$-cryptoxanthin, $\beta$-carotene and neoxanthin (Azevedo-Meleiro \& Rodriguez-Amaya, 2004).

Oil recovery from oleaginous fruits involves various unit operations, such as cleaning, dehulling, maceration, extraction and separation (Freitas et al., 1993). Aqueous extraction at high temperatures is the main method used for pequi pulp oil production in the cerrado area. The yield of aqueous process is low because high viscosity makes stage separation difficult. Additionally, the high temperatures used for viscosity reduction promotes chemical oxidation from unsaturated fatty acids with formation of aldehydes, often responsible for the undesirable flavors in fats and oils (Morales et al., 1995). Recently, the screw pressing is also employed for pequi oil recovery, using technology adapted from other oleaginous fruits (CETEC, 1983).

Enzyme-based process for edible oil extraction is considered to be an environmentally clean technology. The uses of enzymes for oil extraction have been reviewed by Couri and Freitas (2001) and Dominguez et al. (1994). The enzymatic process mainly hydrolyzes the structural polysaccharides, forming the cell wall of oilseeds or the proteins, which form the cell and lipid body membrane (Rosenthal et al., 1994). This technology has been developed in bench scale to extract oil from many vegetable raw materials such as rapeseed, soybean, peanuts, sesame, rice bran corn germ, palm, sunflower; avocado, coconut (Rosenthal, Pyle \& Niranjan, 1996; Hanmoungjai et al., 2001; Caetano et al., 2002; Freitas et al., 2003; Sant'anna et al., 2003). As pointed out by those authors, the main advantage of enzyme-based extraction is a mild operation conditions, which results in a substantial energy savings and a higher yield for the same process.

The enzymatic technology has been applied in industrial scale in order to enhance the yield of extra virgin olive oil (Christensen, 1991). The main factors that affect the hydrolytic process are particle size, moisture, hydrolysis time and the enzyme/ substrate mass ratio (Couri \& Freitas, 2001). The present study aims to compare the yield and quality of pequi pulp oil by applying two methods. In the first, the process has been evaluated by combining the enzymatic treatment and pressing for oil extraction. Before pressing, the hydrolyzed pulp was dried in a tray dryer at $60^{\circ} \mathrm{C}$. Additionally, a simple and efficient process was carried out by combining sun-drying pulp and pressing. The last process can be adopted in rural areas, mainly by indigenous communities living in the Brazilian cerrado regions aiming to achieve a sustainable development.

\section{MATERIALS AND METHODS}

Raw material: the raw fruits ( 70 fruits/plant) were collected on January 2007, in Piaruçu Caiapó community, Xingú, $300 \mathrm{~m}$ from the cerrado plain at $10^{\circ} 46^{\prime} 01.67^{\prime \prime} \mathrm{S}, 5^{\circ} 04^{\prime} 34.10^{\prime \prime} \mathrm{W}$, Mato Grosso State, Brazil. The raw fruits were immediately transported to the laboratory. 


\section{Sample preparation}

Undamaged fresh fruits were sorted, cleaned and immediately autoclaved $\left(121^{\circ} \mathrm{C}, 5 \mathrm{~min}\right.$.) for peroxidase inactivation (Couri \& Freitas, 2001), packed and stored under refrigeration $\left(-18^{\circ} \mathrm{C}\right)$ for subsequent use.

\section{Physicochemical analysis}

The peel, pulp and seeds were manually separated. Pequi pulp proximate composition was analyzed according to AOAC standard methods (2000). Dry matter is determined by oven drying of the sample $(10 \mathrm{~g})$ to constant weight, at $105^{\circ} \mathrm{C}$. Oil content was determined by soxhlet continuous extraction of sample $(5 \mathrm{~g})$ with petroleum ether for 6 hours at solvent boiling point $\left(45\right.$ to $\left.60^{\circ} \mathrm{C}\right)$. Total nitrogen is determined by the Kjeldahl method and protein was calculated applying the factor (5.3) recommended to oleaginous fruits (TACO, 2006). Ash was determined by sample $(3 \mathrm{~g})$ incineration in the muffle furnace at $550^{\circ} \mathrm{C}$ for 5 hours. All analysis was performed in triplicate.

Oil quality index were determined by AOCS official methods (1997). Free fatty acids were measured by titration of the sample (1g) with alkali and the result is expressed as acid value (mg potassium hydroxide required to neutralize $1 \mathrm{~g}$ of fat) (AOCS Cd 3a-63). Peroxide value is measured by oil titrating $(0.5 \mathrm{~g})$ with sodium thiosulphate solution (AOCS Cd 8-53). Iodine values were determined using Wijs' solution. The excess reagent (as iodine) was titrated with sodium thiosulphate solution (AOCS Cd 125 ). Saponification value was expressed as the number of $\mathrm{mg}$ of potassium hydroxide required to saponify one gram of oil or fat (AOCS Cd 3-25).

\section{Fatty acids composition}

The methyl esters (FAME) from pulp oils were prepared by Hartman \& Lago (1973) method. The fatty acids analysis was performed on a HP5890 series II gas chromatography equipped with a fused silica capillary column SP2340 $(60 \mathrm{~m} \times 0.32 \mathrm{~mm}$ x $0.25 \mu \mathrm{m})$ for separation peaks. The temperature program was 150 up to $200^{\circ} \mathrm{C}$ at $1.3^{\circ} \mathrm{C} / \mathrm{min}$. The detector temperatures were set at $250^{\circ} \mathrm{C}$. Sample dilution and the volume injected was $2 \%$ and $1 \mu \mathrm{L}$, respectively, The $\mathrm{H}_{2}$ at $2.5 \mathrm{~mL} / \mathrm{min}$ was used as a carrier gas. Standard fatty acid methyl esters (Sigma Aldrich, Brazil LTDA) were used for identification.

Enzyme preparation: The enzyme was produced in bench-scale reactor by solid state fermentation using a mutant Aspergillus niger 3T5B8 as fermentation agent, according to the methodology improved by Couri et al., (1998). Wheat bran was used as fermentation substrate. The final moisture of the standard medium was adjusted with $0.09 \%$ $(\mathrm{w} / \mathrm{v})$ ammonium sulphate solution in $0.1 \mathrm{M} \mathrm{HCl}$, in order to reach a final moisture level around $60 \%$ and water activity equal to 0.925 . The enzymatic extracts presented mainly polygalacturonase and CMCase activities, respectively of 83 and $21 \mathrm{U} / \mathrm{g}$. One unit of enzyme activity was defined as the amount of enzyme that produce $1 \mathrm{mmol}$ of galacturonic acid/ $\mathrm{min}$ or xylose/min, under the assay conditions.

Drying processes. Sun-drying was carried out by placing the autoclaved pequi fruits directly under sun with average temperature between 30 and $35^{\circ} \mathrm{C}$ to reach thermodynamic equilibrium. Convective-drying was conducted in a tray dryer at $60^{\circ} \mathrm{C}$ and $1 \mathrm{~m} / \mathrm{s}$ air velocity. Batches of $15 \mathrm{~g}$ of samples were placed, in triplicate, in an oven at $105^{\circ} \mathrm{C}$ for 90 minutes to determine the residual moisture content.

Oil Extraction. The oil extraction was carried out using four methods: aqueous extraction at $80^{\circ} \mathrm{C}$, aqueous enzymatic extraction, hydraulic pressing and enzymatic hydrolysis combined with hydraulic pressing at room temperature.

The operational parameters of enzymatic treatments were defined as recommended by Freitas et al., (1998): ratio water/pulp 1:2, enzyme 1\% (relative to the pulp mass), temperature of $45^{\circ} \mathrm{C}$ and incubation time of 90 minutes. The hydrolysis was performed using a temperature-controlled water bath under continuous agitation (50rpm). After the aqueous extractions the mixture was filtered under vacuum, and the liquid phase was centrifuged at 1500rpm during 20 minutes, for oil separation.

Hydraulic pressing. The dried pulp was submitted at 5,000 or 10,000psi during 1 hour in a pilot hydraulic CARVER press.

The recovered oils, for all methods, were weighed and the oil extraction efficiency was calculated by eq. 1 .

Extraction efficiency $(\%)=\frac{\text { mass of extracted oil }}{\text { mass of oil in the sample }} \times 100 .$. [eq. 1 ]

Cake oil extraction. For recovering residual oil, the cake was dried at $60^{\circ} \mathrm{C}$ under convective air and extracted with $95 \% \mathrm{w} / \mathrm{w}$ ethanol (3:1 ratio solvent/substrate) at $65^{\circ} \mathrm{C}$ for 1 hour. The mixture was filtered under vacuum, and the ethanol was removed at negative pressure in a rotary evaporator. 
Statistical analysis. All assays were carried out in triplicate. The average values for each treatment was calculated and the Tukey test was applied $(\mathrm{p}<0.05)$ to evaluate significant difference between mean.

\section{RESULTS}

The fresh pequi fruits presented $71.9 \%$ of peel, $14.3 \%$ of pulp and $13.7 \%$ of nut. The proximate composition of pequi pulp is shown in Table 1. As reported by Martins (1983) and Azevedo-Meleiro \& Rodriguex-Amaya (2004), the lipids are the dominant fraction in dry basis (up to $77 \%$ ). After drying at 35 and $60^{\circ} \mathrm{C}$, the average moisture in the pequi pulp was 25 and $22 \%$, respectively.

The commercial pequi oil presented high acidity $(2.48 \mathrm{mgKOH} / \mathrm{g})$ and high peroxide value $(5.22 \mathrm{meq} / \mathrm{kg})$. These results reveal that hydrolisis and oxidation have occurred in the lipid compounds during commercial oil production.

As can be observed from Table 2 the acidity of aqueous-based oil was similar to the commercial oil value. It occurred, due to high temperature applied $\left(80^{\circ} \mathrm{C}\right)$, which promoted the lipid hydrolysis. As expected, the smaller peroxide value was observed in hexane-based and pressingbased oils ( 0.99 to $1.06 \mathrm{meq} / \mathrm{Kg})$. Compared to all treatments conducted on bench scale, the enzymebased processes have promoted a lipid oxidation in pequi pulp oil (Table 2). Szpiz et al. (1995) have observed an increase in peroxide value in enzymebased avocado oil as compared to solvent-based oil. However, the peroxide and acidity values for all samples, including commercial oil, were lower than AOCS specification for crude oils.

There are no significant differences in iodine values for all treatments (49.13 to 52.03) unless for aqueous enzyme-based oil (74.80). The iodine value is a direct measure of double bonds quantity. The lipid oxidation of unsaturated fatty acids, during enzymatic treatment, leads to the reduction of its content.
It should be observed that the saponification value of pequi oils is smaller for all treatments if compared with commercial oils and literature data. Saponification value is a direct measure of the average molecular weight of the acyl chains of lipids. Those results are in agreement with fatty acids composition of pequi pulp oil. It can be noted (Table 3 ) that pequi pulp oil obtained in this work presented a higher proportion of palmitic acid (C16:0) and a smaller proportion of oleic acid (C18:1) than reported data. Although having the same popular name, these are different fruit varieties and the difference in fatty acids composition is not surprising. According Angerosa et al. (1999) the variations in cultivar, geographic region, fruit maturity, post-harvest handling are the main factors affecting the fatty acids composition in virgin olive oil.

The enzymatic treatment favors the extraction efficiency in about $11 \%$ and $20 \%$ in aqueous process and hydraulic pressing, respectively. The extraction efficiency of pressing ( $40 \%$ ) was superior if compared to aqueous extraction (20\%). This can be explained by the high viscosity of aqueous mixture which causes oil loss during the centrifugation stage. Similar results have been reported by Costa et al., (2002) for aqueous extraction of peach palm oil. In this work, the extraction efficiency reached $68 \%$ after cake-oil recovery using ethanol as solvent (Figure 1). The efficiency of oil extraction by pressing sun-dried pequi fruits was about $30 \%$. The process was enhanced by including oil cake recovery with ethanol, reaching the efficiency of $53 \%$.

The oil extracted is liquid at room temperature and presented a strong yellow coloration, due to the presence of carotenoids (about $179 \mathrm{mg} / 100 \mathrm{~g}$ ). Furthermore, the oil presented both, flavour and taste characteristic of pequi pulp.

TABLE 1 - Proximate composition of pequi pulp, in dry basis

\begin{tabular}{ccccc}
\hline Moisture in fresh fruit (\%) & Oil (\%) & Protein (\%) & Ash (\%) & Carbohydrates (\%)* \\
\hline $48.47 \pm 1.43$ & $70.16 \pm 1.18$ & $2.52 \pm 0.50$ & $1.21 \pm 0.10$ & 26.11 \\
\hline
\end{tabular}

"by difference. 
TABLE 2 - Quality indices of pequi pulp oil

\begin{tabular}{|c|c|c|c|c|}
\hline Extraction method & $\begin{array}{c}\text { Acidity } \\
(\mathrm{mgKOH} / \mathrm{g})\end{array}$ & $\begin{array}{c}\text { Peroxide value } \\
(\mathrm{meg} / \mathbf{k g})\end{array}$ & Iodine value (Wijs). & Saponification value \\
\hline Aqueous (at $\left.80^{\circ} \mathrm{C}\right)^{1}$ & $2.85^{\mathrm{b}}+0.11$ & $1.16^{\mathrm{a}}+0.20$ & $52.03^{\mathrm{a}}+0.00$ & $180.13^{b}+0.78$ \\
\hline \multirow[t]{2}{*}{ Aqueous enzymatic $^{1}$} & $1.35^{\mathrm{c}}+0.09$ & $3.15^{b}+0.35$ & $74.80+0.48$ & $184.23^{b}+2.35$ \\
\hline & \multicolumn{4}{|c|}{ Convective drying at $65^{\circ} \mathrm{C}$} \\
\hline Solvent (petroleum ether) ${ }^{1}$ & $1.11^{\mathrm{a}}+0.00$ & $0.99^{\mathrm{a}}+0.35$ & $51.44^{\mathrm{a}}+0.12$ & $160.15^{\mathrm{a}}+0.86$ \\
\hline Pressing ${ }^{1}$ & $1.33^{\mathrm{c}}+0.07$ & $1.06^{\mathrm{a}}+0.00$ & $51.50^{\mathrm{a}}+0.73$ & $188.41^{\mathrm{b}+4.32}$ \\
\hline \multirow[t]{2}{*}{ Enzyme and pressing ${ }^{1}$} & $1.46^{\mathrm{c}}+0.04$ & $2.98^{b}+0.69$ & $49.13^{\mathrm{a}}+0.35$ & $189.4^{\mathrm{b}}+1.76$ \\
\hline & \multicolumn{4}{|c|}{ Sun drying } \\
\hline Pressing & $0,98^{\mathrm{a}}+0,18$ & $3,65^{b}+0,54$ & $48,65^{\mathrm{a}}+0,05$ & $196,32^{\mathrm{c}}+0,68$ \\
\hline Commercial oils ${ }^{1}$ & $2.48^{\mathrm{b}}+0.02$ & $5.22^{\mathrm{c}}+0.74$ & $51.28^{\mathrm{a}}+0.09$ & $198.48^{c}+3.52$ \\
\hline Literature data ${ }^{2}$ & 1.00 & 1.26 & 53.5 & 202 \\
\hline
\end{tabular}

${ }^{1}$ Obtained in this work; ${ }^{2}$ Martins (1983). Means followed by the same letter $\left({ }^{\mathrm{a}-\mathrm{c}}\right)$ in the column do not differ between them by the Tukey test $(\mathrm{p}<0.05)$.

AOCS specification for crude oil: less than $10 \mathrm{meq} / \mathrm{kg}$; AOCS specification for crude oil: less than $4 \mathrm{mgKOH} / \mathrm{g}$.

TABLE 3- Fatty acids composition of pequi pulp oil.

\begin{tabular}{lcc}
\hline \multicolumn{1}{c}{ Fatty acids (\% p/p) } & Pequi pulp oil ${ }^{1}$ & Pequi pulp oil (Martins, 1983) \\
\hline Palmitic acid (C16:0) & 43.61 & 34.4 \\
Stearic acid (C18:0) & 0.66 & 1.8 \\
Total saturated acids (\%) & 44.27 & 36.2 \\
Oleic acid (C18:1) & 54.55 & 57.4 \\
Linoleic acid C18:2 & 0.84 & 2.8 \\
Linolenic acid C18:3 & 0.18 & 1.0 \\
Total unsaturated acids (\%) & 55.39 & 61.2 \\
\hline \hline
\end{tabular}

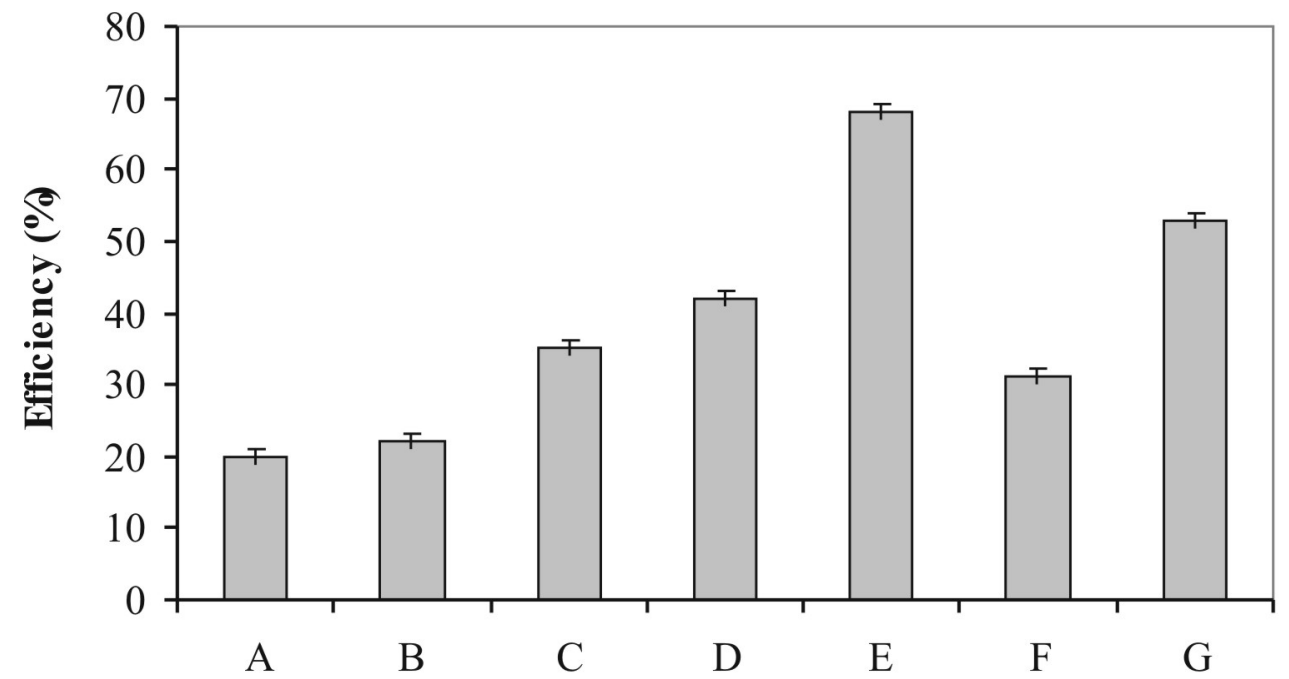

Extraction methods

FIGURE 1 - Efficiency of pequi pulp oil extraction.

A-aqueous; B - aqueous enzymatic; $\mathrm{C}$ - convective drying + hydraulic pressing; D - enzyme + convective drying + hydraulic pressing; $\mathrm{E}$ - enzyme + convective drying + hydraulic pressing + ethanol; F - sun-drying + pressing; G - sun-drying + pressing + ethanol. 


\section{CONCLUSION}

It can be clearly concluded that aqueous extraction has presented a lower efficiency having also promoted a higher oxidation of unsaturated fatty acids. On the other hand, pressing of pequi pulp at room temperature has produced better quality oil. However its efficiency is, yet, smaller than the combined process of enzymatic treatment and pressing. Further investigations are needed to improve the yield of pequi pulp oils produced by pressing of raw-material combined with enzymatic treatment.

\section{ACKNOWLEDGEMENTS}

The authors would like to thank CAPES, CNPq and FAPERJ.

\section{REFERENCES}

ANGEROSA, F.; BASTI, C.; VITO, R. Virgin olive oil volatile compounds from lipoxygenase pathway and characterization of some Italian cultivars. Journal of Agricultural and Food Chemistry, Easton, v.47, p.836-839, 1999.

AOAC -. Association of Official Analytical Chemists. Official methods of analysis. $17^{\text {th }} \mathrm{ed}$. Washington, 2000.

AOCS - American Oil Chemists' Society. Official methods and recommended practices of the american oil chemists society. $4^{\text {th }}$ ed. Champaign, 1997.

AZEVEDO-MELEIRO, C. H.; RODRIGUEZAMAYA, D.B. Confirmation of the identity of the carotenoids of tropical fruits by HPLC-DAD and HPLC-MS. Journal of Food Composition and Analysis, London, v.17, p.385-396, 2004.

CAETANO, M.F.; COURI, S.; FREITAS, S.P. Enzymatic aqueous extraction of sunflower oil from extruded kernels. La Rivista Italiana delle Sostanze Grasse, Milano, v.79, p.165-169. 2002.

CETEC - Fundação Centro Tecnológico de Minas Gerais. Programa Energia. Produção de combustíveis líquidos a partir de óleos vegetais. Belo Horizonte, 1983.
CHRISTENSEN, F.M. Extraction by aqueous enzymatic process. Inform, v.1, p.984-987, 1991.

COSTA, A.C.A.; FREITAS, S.P.; COURI, S.; PINTO, G.A.S. Aqueous extraction of peach palm oil. Brazilian Journal of Food technology, Campinas, v.5, p.211-216, 2002.

COURI, S.; FREITAS, S.P. Aplicação de enzimas na extração aquosa de óleos vegetais. In: PASTORE, G. (Org.). Ciência de alimentos: avanços e perspectivas. Campinas: Ed. UNICAMP, 2001. p.28-32.

COURI, S.; TERZI, S.C.; SILVA, F.; FREITAS, S.P.; PINTO, G.A.S. Seleção de linhagens mutantes de Aspergillus niger, para síntese de enzimas hidrolíticas por fermentação em meio semissólido. Ciência \& Engenharia, Uberlândia, v.2, p.29-31,1998.

DOMINGUEZ, H.; NUNEZ, M.J.; LEMA, J.M. Enzymatic pre-treatment to enhance oil extraction from fruits and oilseeds: a Review. Food Chemistry, Oxford, v.49, p.271-286, 1994.

FREITAS, S.P.; LAGO, R.C.A.; JABLONKA, F.H.; HARTMAN, L. Extraction aqueuse enzymatique de l'huile d' avocat à partir de la pulpe fraîche. Revue Française des Corps Gras, Paris, v.40, p.365371,1993 .

FREITAS, S.P.; VASCONCELOS, C.C.; HAMACHER, M.S.; PINTO, G.S. Tecnologia enzimática para extracción simultánea del aceite e proteína del ajonjoli. Alimentaria,Madrid, n. 339, p.43-48, 2003.

FREITAS, S.P.; YAHYA, Q.R.; LAGO, R.C.A. Economics analysis of enzymatic extraction of avocado oil,. La Rivista Italiana Delle Sostanze Grasse, Milano, v.75, p.15-19,1998.

HANMOUNGJAI, D.L.; PYLE, D.E.; NIRANJAN, $\mathrm{K}$. Enzymatic process for extraction oil and protein from rice bran. Journal of the American Oil Chemists' Society, Champaign, v.78, p.817-821, 2001.

HARTMAN, L.; LAGO, R.C.A. Rapid preparation of fatty acids methyl esters. Laboratory Practice, London, v.22, 475-476, 1973.

LEITE G.L.D.; VELOSO, R.V.S.; ZANUNCIO, J.C.; FERNANDES, L.A.; ALMEIDA. C.I.M. Phenology of Caryocar brasiliense in the Brazilian 
cerrado region. Forest Ecology and Management, Amsterdam, v.236, p.286-294, 2006.

LIMA, A.; SILVA, A.M. de O.; TRINDADE, R.A.; MANCINI-FILHO, J. Composição química e compostos bioativos presentes na polpa e na amêndoa do pequi (Caryocar brasiliense, Camb.). Revista Brasileira de Fruticultura, Jaboticabal, v.29, p.695-698, 2007.

MARTINS, H. Estudo das oleaginosas nativas de Minas Gerais. Belo Horizonte: Fundação Centro Tecnológico de Minas Gerais/CETEC,1983. v.1, $152 \mathrm{p}$.

MORALES, M.T.; ALONSO, M.V.; RIOS, J.J.; APARICIO R. Virgin olive oil aroma: relationship between volatile compounds and sensory attributes by chemometrics, Journal of Agricultural and Food Chemistry, Easton, v.43, p.2925-2931,1995.

ROESLER, R.; CATHARINO, R.R.; MALTA, L.G.; EBERLIN, M.N.; PASTORE, G. Antioxidant activity of Caryocar brasiliense (pequi) and characterization of components by electrospray ionization mass spectrometry. Food Chemistry, Oxford, v. 110, p.711-717, 2008.
ROSENTHAL, A.; PYLE, D.E.; NIRANJAN, $\mathrm{K}$. Aqueous and enzymatic process for edible oil extraction, Enzyme Microbiology Technology, Surrey, v.19, p.402-420, 1996.

SANT'ANNA, B.M.P.; COELHO, M.A.Z.; FREITAS, S.P. Enzymatic aqueous technology for simultaneous coconut protein and oil extraction . Grasas y Aceites, Sevilla, v.54, p.15-19, 2003.

SZPIZ, R.R.; PEREIRA, D.A.; GODOY, R.L. de O.; JABLONKA, F.H.; LAGO, R.C.A. Influence of Extraction Method on the Composition of Avocado Oil Unsaponifiable Matter. In: SCIENTIFIC PROGRAM OF FOOD SCIENCE LATIN AMERICAN SYMPOSIUM, 1995. Campinas. p.11.

TACO- Tabela Brasileira de Composição de Alimentos. versão 2. Campinas: Núcleo de estudos e Pesquisa em Alimentação, 2006. 